Volume 09, Nomer 03, 2019

\title{
Efektifitas Stimulasi Oral Terhadap Reflek Hisap Lemah Pada BBLR
}

\author{
Heri Saputro*, Feri Megawati \\ Departemen Keperawatan, Institut Ilmu Kesehatan STRADA Indonesia \\ Email : h.saputro@iik-strada.ac.id
}

\begin{abstract}
Abstrak
Pendahuluan: Reflek hisap yang masih lemah menyebabkan bayi mempunyai reflek menelan yang lemah pula. Bayi dengan reflek hisap yang lemah menyebabkan bayi tidak mampu memenuhi kebutuhan nutrisi secara maksimal, sehingga berat badan bayi menjadi rendah. Untuk mengatasi hal ini maka diupayakan untuk memberi stimulasi oral terhadap reflek hisap.

Tujuan: Untuk mengetahui efektifitas pemberian stimulasi oral setelah terhadap reflek hisap lemah pada bayi

Metode: Desain penelitian ini adalah one group pretest posttest dengan pendekatan cross sectional sejumlah 30 bayi. Teknik sampling yang digunakan adalah consecutive sampling

Hasil: refleks hisap bayi BBLR sebelum dilakukan stimulasi oral di IRNA Mawar RSUD dr. Iskak Tulungagung dari 30 responden, semua bayi BBLR mengalami refleks hisap lemah (100\%), sedangkan dilakukan stimulasi oral memberikan efektifitas pada bayi BBLR dengan reflek hisap kuat sebesar 23 bayi $(76,7 \%)$. Uji statistik menggunakan Paired Sample T-Test diperoleh nilai $p$ value $=0,000<0,05 \alpha$ sehingga $\mathrm{H} 0$ ditolak dan $\mathrm{H} 1$ diterima.

Kesimpulan: Stimulasi oral sangat bermanfaat untuk meningkatkan kekuatan refleks hisap bayi, karena stimulasi oral dapat merangsang nervus X (nervus vagus), sehingga mengaktifkan refleks pada nervus $\mathrm{X}$ dan merangsang timbulnya rasa lapar pada bayi
\end{abstract}

Kata Kunci: stimulasi oral, reflek hisap, berat badan lahir rendah

\begin{abstract}
Introduction: Infants with low birth weight have a disorder in the nervous system and organ function that can affect the suction reflex in the baby. The weak suction reflection causes the baby to have a weak swallowing reflex as well. Infants with weak suction reflexes cause the baby is unable to meet the nutritional needs to the maximum, so the baby's weight becomes low. To overcome this it is attempted to give oral stimulation of the suction reflex.

Objective: to determine the effectiveness of oral stimulation of weak suction reflex in infants BBLR Method: The design of this study was a one group pretest posttest with a cross sectional approach of 30 babies. The sampling technique used was consecutive sampling
\end{abstract}

Results: The results showed the suction reflex of infant BBLR before done oral stimulation in IRNA Mawar RSUD dr. Iskak Tulungagung from 30 respondents, all BBLR infants had a weak suction reflex $(100 \%)$, whereas after oral stimulation gave effectiveness in LBW infants with strong suction reflexes of 23 babies (76.7\%). The statistical test using Chi-Square Test obtained p value $=0.000<$ $0,05 \alpha$ so that HO is rejected and HI accepted.

Conclusion: Oral stimulation is helpful for increasing the strength of the baby's suction reflex, because oral stimulation can stimulate the $X$ nerve (vagus nerve), thus activating reflexes in the $X$-nerve and stimulating the emergence of hunger in infants

Keywords: oral stimulation, suction reflexes, low birth weigh, 


\section{Pendahuluan}

Berat Badan Bayi Lahir Rendah (BBLR) adalah bayi baru lahir yang berat badan pada saat kelahiran kurang dari 2.500 gram. Dahulu neonates dengan berat badan lahir kurang dari 2.500 gram atau sama dengan 2.500 gram disebut prematur. Menurut World Health Orgamization (WHO) semua bayi yang baru lahir dengan berat lahir kurang dari 2.500 gram disebut Low Birth Weight Infants (BBLR). Ciri-ciri bayi baru lahir sehat berat badan 2.500-4000 gram dengan panjang badan $48-52 \mathrm{~cm}$, lingkar dada $30-38 \mathrm{~cm}$, lingkar kepala 33-35 cm, frekuensi jantung 120-160 kali/menit, pernafasan kurang lebih 60-40 kali/menit. Bayi baru lahir rendah memiliki tiga gerak reflek bayi, yaitu reflek hisap dan menelan, reflek morrow atau gerak memeluk bila dikagetkan, dan reflek graps atau menggenggam.

Perkiraan WHO pada hampir semua atau $98 \%$ dari lima juta kematian neonatal terjadi di negara berkembang, lebih dari dua pertiga kematian itu terjadi pada periode neonatal dini, umumnya dikarenakan berat badan lahhir kurang dari 2.500 gram. Menurut WHO, 17\% dari 25 juta kehamilan pertahun adalah BBLR dan hampir semua terjadi di negara berkembang.

Menurut Survei Penduduk Antar Sensus (SUPAS) tahun 2015, angka kematian bayi di Indonesia tahun 2015 sebesar 22,23\% per 1000 kelahiran hidup (Profil kesehatan Indonesia). Di Jawa Timur angka kematian bayi tahun 2014 sebesar $26,66 \%$ per 1000 kelahiran hidup. Jumlah kabupaten atau kota yang memiliki AKB di atas angka provinsi adalah sebesar $52,63 \%$, tertinggi di kabupaten Probolinggo mencapai $61,48 \%$ dan terendah di kabupaten Blitar yaitu sebesar 17,99\%. Di Kabupaten Tulungagung pada tahun 2015 angka kematian bayi mencapai 9,45 per 1000 kelahiran hidup. Jumlah yang mati yaitu 142 jiwa dari 15.019 jiwa kelahiran (Profil Kesehatan Tulungagung 2015). Di RSUD dr. Iskak sendiri pada tahun 2016 terdapat 366 kasus kematian bayi dengan 28 bayi diantaranya bayi BBLR (data IRNA Mawar RSUD dr. Iskak Tulungangung).

Salah satu upaya untuk membantu BBLR adalah dengan pemberian ASI langsung, namun pada BBLR terdapat kelemahan dalam daya hisap. Untuk mengatasi hal ini maka diupayakan untuk memberi stimulasi oral terhadap reflek hisap, yaitu melatih oral BBLR untuk dapat menghisap secara langsung pada saat memberikan ASI. Metode stimulasi oral sudah mulai disosialisasikan, dan lebih disukai karena lebih aman dan murah. ${ }^{3}$ Melalui sentuhan dan stimulasi terutama jaringan otot daerah sekita mulut dapat meningkatkan peredaran darah, meningkatkan fungsi otot dan merangsang refleks hisap pada bayi terutama pada bayi BBLR serta dapat meningkatkan fungsi organ tubuh lainnya. ${ }^{4}$

Keterampilan oral bayi prematur dibagi ke dalam 4 fase, yaitu berkembangnya reflek menghisap, kematangan proses menelan, kematangan fungsi pernafasan, koordinasi gerakan menghisap, menelan dan bernafas. Komponen refleks menghisap sudah mulai ada sejak usia kehamilan 28 mingu, namun sinkronasi masih tidak teratur, dan bayi mudah mengalami kelelahan. Sejalan dengan proses pematangan, maka mekanisme yang lebih teratur akan didapatkan pada usia kehamilan 32-36 minggu. Berbagai penelitian telah dikemukakan hubungan yang kuat antara kematangan bayi dan teroganisirnya pola suckling. Penelitian Jones membuktikan bahwa masa transisi dapat dipercepat dengan paparan suckling lebih dini.

Stimulasi oral khusus yang memberikan bantuan gerakan untuk mengaktifkan kontraksi otot dan untuk memberikan gerakan terhadap perlawanan untuk membangun kekuatan. Fokus intervensi ini adalah untuk meningkatkan respon fungsional terhadap tekanan dan gerakan, jangkauan, kekuatan, dan pengendalihan berbagai gerakan bibir, pipi, rahang, dan lidah. Intervensi yang ditentukan oleh penilaian kemampuan oral. Perangkat yang dilakukan adalah dengan mengunakan gerakan dibantu dan reflek peregangan untuk mengukur respon terhadap 
tekanan dan gerakan, jangkauan, kekuatan, dan kontrol berbagai gerakan untuk pipi, bibir, rahang, lidah dan langit-langit lunak. Inilah cara yang dilakukan pada motorik BBLR untuk dapat menghisap secara langsung pada saat mendapatkan ASI.

Berdasarkan fenomena di atas maka peneliti tertarik melakukan penelitian tentang "Efektifitas Stimulasi Oral Terhadap Reflek Hisap Lemah pada BBLR di IRNA Mawar RSUD dr. Iskak Tulungagung. Adapun rumusan masalah dalam penelitian ini adalah "Bagaimana efektifitas stimulasi oral terhadap reflek hisap lemah pada BBLR di IRNA Mawar RSUD dr. Iskak Tulungagung?

\section{Metode \\ Desain Penelitian}

Dalam penelitian ini desain yang digunakan adalah pretest, posttest dengan pendekatan cross sectional yaitu kelompok subjek yang memenuhi kriteria inklusi dari peneliti, sebelum menerima perlakuan terlebih dahulu dilakukan observasi, kemudian setelah menerima perlakuan dilakukan observasi ulang untuk mengetahui akibat dari perlakuan tersebut, dimana kedua variabel diukur dalam waktu yang bersamaan. Dalam penelitian ini, penulis menggunakan desain penelitian one group pretest posttest.

\section{Populasi, Sampel dan Sampling}

Populasi dalam penelitian ini adalah seluruh bayi yang lahir dengan Berat Badan Lahir Rendah (BBLR) yang mempunyai reflek hisap lemah yang dirawat di IRNA Mawar RSUD dr. Iskak Tulungagung sejumlah 40 bayi. Sampel dalam penelitian ini adalah bayi yang lahir dengan Berat Badan Lahir Rendah (BBLR) yang dirawat di IRNA Mawar RSUD dr. Iskak Tulungagung sejumlah 30 bayi.

Cara sampling yang digunakan dalam penelitian ini dilakukan dengan Consecutive Sampling, yaitu pengambilan sampel dengan memilih sampel yang memenuhi kriteria inklusi sampai kurun waktu tertentu sehingga jumlah sampel terpenuhi.

\section{Variabel Penelitian}

Variabel independent dalam penelitian ini adalah stimulasi oral. Sedangkan variabel dependent penelitian ini adalah reflek hisap lemah pada BBLR.

\section{Bahan dan Instrumen}

Variabel dependen diukur dengan menggunakan lembar observasi. Observasi atau pengamatan adalah sesuatu yang terencana, meliputi melihat dan mencatat jumlah serta taraf aktifitas tertentu yang ada hubungannya dengan masalah yang diteliti.

Observasi akan dilakukan pada kelompok Bayi Berat Lahir Rendah (BBLR) dengan reflek hisap lemah. Bayi tersebut akan diberikan tindakan stimulasi oral sesuai dengan SOP dan dilaksanakan sehari 2 kali, yaitu pagi dan sore. Setelah dilakukan tindakan stimulasi oral, bayi diamati lagi untuk mengetahui apakah refleks hisap bayi meningkat atau tidak dengan cara diberi minum lewat sendok. Hasil dari observasi dicatat di lembar observasi. Hasil observasi yang didapatkan akan menjadi tolak ukur evaluasi peneliti.

\section{Hasil}

Penelitian ini dilakukan di IRNA Mawar RSUD dr. Iskak Tulungagung bagian Perinatologi yang mempunyai kapasitas jumlah tempat tidur NICU 8, HCU 8, Isolasi 3, Persiapan RG 10 dan jumlah total ada 29. Tersedia pula Dapur Susu, Ruang lbu Meneteki, Ruang Tindakan dan Tempat Linen. Dengan ketenagaan 4 orang dokter spesialis anak, 22 orang perawat, 1 orang tenaga administrasi dan 1 orang asper.

Tabel 1. Karakteristik Responden Berdasarkan Reflek Hisap Bayi BBLR Sebelum Perlakuan Stimulasi Oral

\begin{tabular}{ccc}
\hline Reflek & \multicolumn{2}{c}{ Sebelum Stimulasi Oral } \\
\cline { 2 - 3 } Hisap & $\mathbf{n}$ & $\mathbf{\%}$ \\
\hline Lemah & 30 & 100 \\
Kuat & 0 & 0 \\
\hline Jumlah & 30 & 100 \\
\hline
\end{tabular}

Karakteristik responden berdasarkan refleks hisap sebelum dilakukan stimulasi oral di IRNA Mawar RSUD dr. Iskak 
Tulungagung Tahun 2017 menunjukkan bahwa, dari 30 responden semua bayi BBLR mengalami refleks hisap lemah (100\%).

Tabel 2. Karakteristik Responden Berdasarkan Reflek Hisap Bayi BBLR Setelah Perlakuan Stimulasi Oral

\begin{tabular}{ccc}
\hline Reflek & \multicolumn{2}{c}{ Setelah Stimulasi Oral } \\
\cline { 2 - 3 } Hisap & $\mathbf{n}$ & \% \\
\hline Lemah & 7 & 23,3 \\
Kuat & 23 & 76,7 \\
\hline Jumlah & 30 & 100 \\
\hline
\end{tabular}

Karakteristik responden berdasarkan refleks hisap sebelum dilakukan stimulasi oral di IRNA Mawar RSUD dr. Iskak Tulungagung Tahun 2017 menunjukkan bahwa, sebagian besar responden sesudah dilakukan stimulasi oral, refleks hisap bayi BBLR menjadi kuat yaitu sebesar 23 bayi (76,7\%).

Tabel 3. Tabulasi Silang Variabel

\begin{tabular}{|c|c|c|c|c|c|c|c|}
\hline \multirow{3}{*}{$\begin{array}{c}\text { Stimulasi } \\
\text { Oral }\end{array}$} & \multicolumn{4}{|c|}{ Reflek Hisap } & \multirow{2}{*}{\multicolumn{2}{|c|}{ Total }} & \multirow{3}{*}{$\begin{array}{c}P \\
\text { Value }\end{array}$} \\
\hline & \multicolumn{2}{|c|}{ Lemah } & \multicolumn{2}{|c|}{ Kuat } & & & \\
\hline & n & $\%$ & $\mathbf{n}$ & $\%$ & $\mathrm{n}$ & $\%$ & \\
\hline \multicolumn{8}{|l|}{ Sebelum } \\
\hline Stimulasi & 30 & 100 & 0 & 0 & 30 & 100 & \multirow{5}{*}{0,000} \\
\hline Oral & & & & & & & \\
\hline Setelah & & & & & & & \\
\hline Stimulasi & 7 & 23,3 & 23 & 76,7 & 30 & 100 & \\
\hline Oral & & & & & & & \\
\hline
\end{tabular}

Berdasarkan hasil tabulasi silang tabel 3 di atas dapat diketahui bahwa stimulasi oral memang memberikan dampak yang positif bagi perubahan reflek hisap bayi BBLR. Berdasarkan penelitian tersebut, reflek hisap bayi BBLR yang belum diberlakukan stimulasi oral cenderung mempunyai reflek hisap lemah. Kemudian setelah diberlakukan stimulasi oral, reflek hisap bayi menjadi kuat, dari 30 responden, bayi BBLR yang sebelumnya memiliki reflek hisap lemah menjadi kuat sebanyak 23 bayi $(76,7 \%)$. Tentunya hal tersebut tergantung pada kondisi fisik bayi, berat badan bayi, lama rawat inap dimana kesemuanya berkaitan dengan proses pemberian stimulasi oral motor pada responden.

Tabel 5. Hasil Uji Statistik

\begin{tabular}{|c|c|c|c|c|c|c|c|c|c|}
\hline \multicolumn{10}{|c|}{ Paired Samples Test } \\
\hline & \multicolumn{9}{|c|}{ Paired Differences } \\
\hline & & & $\begin{array}{l}\text { Std } \\
\dot{D e}\end{array}$ & & $\begin{array}{r}95 \% \text { Co } \\
\text { Interva } \\
\text { Diffe }\end{array}$ & $\begin{array}{l}\text { nfidence } \\
1 \text { of the } \\
\text { rence }\end{array}$ & & & $\begin{array}{l}\text { Sig } \\
\text {. }\end{array}$ \\
\hline & & $\begin{array}{l}\mathrm{Me} \\
\text { an }\end{array}$ & tio & $\begin{array}{l}\text { Error } \\
\text { Mean }\end{array}$ & Lower & Upper & $\mathrm{t}$ & df & $\begin{array}{l}\text { tail } \\
\text { ed) }\end{array}$ \\
\hline Pair 1 & $\begin{array}{l}\text { Sebelum } \\
\text { Stimulasi } \\
\text { Oral - } \\
\text { Setelah } \\
\text { Stimulasi } \\
\text { Oral }\end{array}$ & $\begin{array}{r}- \\
.76 \\
66 \\
7\end{array}$ & $\begin{array}{r}.43 \\
01 \\
8\end{array}$ & $\begin{array}{r}.0785 \\
4\end{array}$ & -.92730 & -.60603 & $\begin{array}{r}- \\
9.7 \\
61\end{array}$ & 29 & $\begin{array}{r}.00 \\
0\end{array}$ \\
\hline
\end{tabular}

Berdasarkan hasil uji Paired Sample TTest diperoleh nilai $\mathrm{p}$ value $=0,000<0,05 \alpha$, sehingga $\mathrm{H}_{0}$ ditolak dan $\mathrm{H}_{1}$ diterima. Terdapat perbedaan daya hisap bayi BBLR sebelum dan sesudah diberikan stimulasi oral. Dengan demikian terdapat efektifitas pemberian stimulasi oral terhadap reflek hisap lemah pada bayi BBLR di IRNA Mawar RSUD dr. Iskak Tulungagung.

\section{Pembahasan}

Mengidentifikasi Reflek Hisap Pada Kelompok Bayi yang Mempunyai Berat Badan Lahir Rendah Sebelum Diberikan Perlakuan Stimulasi Oral di IRNA Mawar RSUD dr. Iskak Tulungagung

Berdasarkan data hasil penelitian sebagaimana yang dapat dijelaskan bahwa, dari 30 responden yang diambil sebagai sampel penelitian semua mengalami refleks hisap lemah $(100 \%)$.

Komponen refleks menghisap sudah mulai ada sejak usia kehamilan 28 minggu, namun sinkronisasi masih tidak teratur, dan bayi mudah mengalami kelelahan. Sejalan dengan proses pematangan, maka mekanisme yang lebih teratur akan didapatkan pada usia kehamilan 32-36 minggu. Berbagai penelitian telah dikemukakan hubungan yang kuat antara kematangan bayi dan terorganisirnya pola suckling. penelitian Jones tahun 2003 membuktikan bahwa mass transisi dapat dipercepat dengan paparan suckling lebih dini.

Pada penelitian ini semua bayi BBLR tidak dimasukkan ke dalam kriteria penelitian. 
Sebagaimana data yang telah disebutkan dalam latar belakang penelitian, bahwa di RSUD dr. Iskak Tulungagung masalah yang terbesar dari BBLR adalah imaturitas refleks hisap yang lemah yaitu sebesar $70 \%$, sehingga dalam penelitian ini hanya bayi BBLR yang mengalami refleks hisap lemah saja yang diteliti. Bayi dengan BBLR seringkali menimbulkan masalah antara lain hipotermi, sindroma gawat nafas, perdarahan intrakranial, hiperbillirubinemia dan hipoglikemi akibat dari refleks hisap yang lemah. Hal ini diakibatkan imaturitas dari fungsi dari organ-organ vitalnya.

Bayi dengan refleks hisap lemah sebelum dilakukan stimulasi oral sangat berpengaruh terhadap asupan nutrisi. Bila nutrisi bayi tidak terpenuhi, akibat yang paling nyata adalah akan terjadi penurunan berat badan yang akan berakibat pada kondisi-kondisi patologis lainnya seperti yang sudah disebutkan di atas. Pada keadaan ini tidak dilakukan penatalaksanan secara baik maka bayi akan jatuh dalam kondisi yang lebih berat, akibatnya masa perawatan di rumah sakit akan semakin panjang, bila hal ini terjadi keluarga akan semakin terbebani oleh biaya yang besar dan ancaman terjadinya infeksi nosokomial semakin besar pula. Dengan demikian bayi akan terancam integritasnya.

\section{Mengidentifikasi Reflek Hisap Pada Kelompok Bayi yang Mempunyai Berat Badan Lahir Rendah Setelah Diberikan Perlakuan Stimulasi Oral di IRNA Mawar RSUD dr. Iskak Tulungagung}

Berdasarkan data di atas menunjukkan bahwa, sebagian besar responden setelah dilakukan stimulasi oral adalah dengan refleks hisap kuat yaitu sebesar 23 bayi atau 76,7\%.

Stimulasi oral adalah suatu sentuhan dan pijatan pada jaringan otot daerah sekitar mulut untuk melancarkan peredaran darah dan merangsang syaraf-syaraf yang akan memberikan pengaruh yang positif. ${ }^{13}$ Selain itu, juga bisa dikatakan berbagai strategi dan teknik yang telah dilakukan dalam teknik stimulasi, seperti menyikat (pijat tekanan) tulang pipi, caranya memutar ke arah luar dilakukan 1 kali dan 3 kali, kemudian icing (stimulasi termal), peregangan cepat (penyadapan), dan getaran (manual dan mekanis). Stimulasi oral dilakukan untuk mempersiapkan area otot untuk gerakan. Strategi ini tidak dapat mengubah rentang pergerakan otot atau kekuatan otot tanpa gerakan otot tambahan.

Beberapa langkah dalam melakukan stimulasi oral adalah dengan melakukan pemijatan yang diawali dari daerah sekitar hidung, diakhiri pada daerah rahang bayi. Teknik yang dapat dilakukan adalah dengan senyum I, senyum II, senyum III, dan lingkaran kecil dirahang (small circles around jaw).

Reflek hisap yang kuat pada bayi terjadi 30 menit setelah melahirkan, sehingga sangat dianjurkan jika reflek bayi kuat dalam waktu 30 menit diberikan ASI. Tanda reflek hisap yang kuat yaitu apabila diberikan rangsangan pada mulut bayi, maka bayi segera menghisapnya. Refleks ini merupakan reaksi yang inheren (built in) terhadap rangsangan tertentu dan bayi kecil secara otomatis akan memberikan respons penyesuaian diri terhadap lingkungan mereka. Refleks mengatur gerakan-gerakan bayi yang baru lahir. Sifat refleks ini adalah otomatis dan di luar kendali bayi yang baru lahir tersebut. ${ }^{7}$ Kemampuan menghisap bayi yang baru lahir berbeda-beda. Sebagian bayi yang baru lahir menghisap dengan efisien dan bertenaga untuk memperoleh susu, sementara bayi-bayi lain tidak begitu terampil dan kelelahan bahkan sebelum mereka kenyang.

Untuk meningkatkan kekuatan refleks hisap pada bayi dengan BBLR ini perlu dilakukan suatu usaha untuk meningkatkannya, yaitu dengan melakukan stimulasi. Stimulasi yang dapat dilakukan adalah dengan melakukan stimulasi oral. Memberikan stimulasi sejak dini berupa sentuhan pemijatan terhadap jaringan otot di sekitar mulut. Melalui sentuhan dan stimulasi terutama jaringan otot daerah sekitar mulut dapat meningkatkan peredaran darah, meningkatkan fungsi otot dan merangsang refleks hisap pada bayi. Selain adanya peningkatan fungsi otot di sekitar mulut, efek lain dari sentuhan pemijatan 
terhadap jaringan otot di sekitar mulut (stimulasi oral) ini adalah merangsang nervus $\mathrm{X}$ (nervus vagus), sehingga mengaktifkan refleks pada nervus $X$ dan merangsang timbulnya rasa lapar pada bayi. Efek inilah yang menyebabkan refleks hisap bayi semakin meningkat. Berdasarkan data penelitian di atas, stimulasi oral sangat bermanfaat untuk meningkatkan kekuatan refleks hisap.

\section{Menganalisa Efektifitas Pemberian Stimulasi Oral Terhadap Reflek Hisap Pada Bayi BBLR di IRNA Mawar RSUD dr. Iskak Tulungagung}

Berdasarkan hasil Uji Paired Sample TTest diperoleh nilai $\mathrm{p}$ value $=0,000<0,05 \alpha$. Dengan demikian $\mathrm{H}_{0}$ ditolak dan $\mathrm{H}_{1}$ diterima, artinya ada efektifitas pemberian stimulasi oral terhadap reflek hisap lemah pada bayi BBLR di IRNA Mawar RSUD dr. Iskak Tulungagung.

Pemberian stimulasi oral motor pada BBLR dalam pelaksanaannya diberikan selama 3- 5 detik. Berbagai penelitian telah dikemukakan hubungan yang kuat antara kematangan bayi dan terorganisirnya pola suckling. penelitian Jones tahun 2003 membuktikan bahwa masa transisi dapat dipercepat dengan paparan suckling lebih dini.

Pada hakekatnya manusia dilahirkan untuk mempertahankan hidupnya menggunakan naluri dan refleksnya. Refleks ini timbul oleh karena rangsangan yang berasal dari luar dirinya melalui pendengaran, penglihatan, dan perabaan dari kulitnya. Sehingga bayi yang baru lahir akan menggunakan reflex-refleks primitifnya seperti; rooting, sucking, dan lainlain. Bayi baru lahir dengan berat badan yang rendah mempunyai ketidakmaturan dalam sistem persarafan dan fungsi organ sehingga reflek-reflek tersebut lemah. Walaupun seiring dengan berjalannya waktu dan dengan bertambahnya umur bayi kemampuannya akan meningkat, akan tetapi hal ini akan meningkatkan ketergantungan bayi akan terapi nitrisi yang tidak fisiologis (infus dan sonde) akibatnya meningkatkan morbiditas dan mortalitas bayi dengan BBLR. Dengan demikian bayi akan semakin lama dirawat di rumah sakit dan ini akan meningkatkan risiko terjadinya infeksi nosokomial.

Bayi Berat Badan Lahir Rendah (BBLR) adalah bayi baru lahir yang berat badan lahimya pada saat kelahiran kurang dari 2.500 gram. Dahulu neonates dengan berat badan lahir kurang dari 2.500 gram atau sama dengan 2.500 gram disebut prematur. Berat badan lahir rendah (BBLR) ialah bayi baru lahir yang berat badan lahimya pada saat kelahiran kurang dari 2500 gram.

Pada bayi dengan berat badan lahir rendah salah satu penatalaksanaan yang perlu diperhatikan adalah pengawasan pemberian nutrisi harus dengan cermat dan seksama. Hambatan yang terdapat pada BBLR sehubungan dengan pengawasan nutrisi adalah reflek hisap bayi yang belum sempurna atau masih lemah. Oleh sebab itu, pemberian nutrisi harus dengan cermat. Bayi dengan reflek hisap yang kuat ASInya diberikan $1 / 2$ jam setelah lahir, sedangkan bayi dengan reflek hisap yang lemah, ASI diberikan khusus dengan sonde.

Intervensi ini khusus yang memberikan bantuan gerakan untuk mengaktifkan kontraksi otot dan untuk memberikan gerakan terhadap perlawanan untuk membangun kekuatan. Fokus intervensi ini adalah untuk meningkatkan respons fungsional terhadap tekanan dan gerakan, jangkauan, kekuatan, dan pengendalian berbagai gerakan bibir, pipi, rahang dan lidah. Oral motor merupakan ketrampilan dasar kelangsungan hidup dampak seperti mengisap dan menelan dengan bayi yang mulai dengan bulan ketiga kehamilan.

Reflek hisap yang kuat pada bayi terjadi 30 menit setelah melahirkan, sehingga sangat dianjurkan jika reflek bayi kuat dalam waktu 30 menit diberikan ASI. Tanda reflek hisap yang kuat yaitu apabila diberikan rangsangan pada mulut bayi, maka bayi segera menghisapnya. Reflek hisap yang masih lemah pada bayi ditandai dengan bayi malas menetek, reflek batuk belum sempuma, dan tidak segera tanggap atau dihisap apabila diberikan rangsangan pada mulutnya. 
Penjelasan di atas memberikan gambaran bahwa pemberian stimulasi oral pada BBLR sangat penting untuk menimbulkan rangsangan reflek hisap yang lemah menjadi lebih kuat. Hal ini menunjukkan bahwa hasil penelitian mempunyai kesesuaian dengan teori bahwa reflek stimulasi oral memberikan pengaruh yang signifikan terhadap reflek hisap pada bayi BBLR. Pada dasarnya reflek hisap tidak dipengaruhi oleh jenis kelamin maupun berat badan bayi. Reflek hisap cenderung berkaitan dengan kematangan saraf, karena reflek hisap ditimbulkan rangsangan saraf kranial yang terdiri dari saraf Trigeminus, Fasialis, Glosofaringeus dan Vagus. Apabila bayi lahir prematur, maka saraf-saraf tersebut belum matang sehingga pada bayi prematur selalu diikuti oleh reflek hisap yang lemah. Dengan stimulasi oral motor pada bayi BBLR harapannya adalah dapat memperkuat reflek hisap. Reflek hisap yang kuat dapat diketahui apabila mulut bayi dirangsang dengan jari dan puting susu maka bayi langsung menghisap dengan kuat. Sedangkan reflek hisap yang lemah atau belum kuat ditandai dengan bayi sering berhenti menghisap saat minum ASI. Reflek hisap sangat penting bagi pengawasan dan perkembangan asupan nutrisi pada bayi. Dengan demikian terdapat efektifitas stimulasi oral terhadap reflek hisap lemah pada bayi BBLR.

\section{Kesimpulan}

Refleks hisap bayi Berat Badan Lahir Rendah sebelum dilakukan stimulasi oral di IRNA Mawar RSUD dr. Iskak Tulungagung dari 30 responden, semua bayi BBLR mengalami refleks hisap lemah, Refleks hisap bayi Berat Badan Lahir Rendah setelah dilakukan stimulasi oral di IRNA Mawar RSUD dr. Iskak Tulungagung dari 30 responden sebagian besar adalah dengan refleks hisap kuat sebesar 23 bayi,Stimulasi oral mempunyai efektifitas yang signifikan terhadap refleks hisap pada bayi dengan Berat Badan Lahir Rendah (BBLR) di IRNA Mawar RSUD dr. Iskak Tulungagung.

\section{Daftar Pustaka}

1. Yushananta. Perawatan Bayi Resiko Tinggi. Jakarta: Gramedia Pustaka Utama; 2003.

2. Octavia, Susanti. Faktor-Faktor yang Berhubungan dengan Kejadian BBLR di RS Urip Somoharjo Lampung. Skripsi. Lampung: STIKes Mitra Lampung; 2006.

3. Lismayani. Perawatan Bayi Resiko Tinggi. Jakarta: EGC; 2007.

4. Manuaba, Ida Bagus Gede. Ilmu Kebidanan, Penyakit Kandungan \& KB. Jakarta: EGC; 2008.

5. Sugiyono. Statistik Non Parametris. Bandung: Alfa Beta; 2001.

6. Notoadmodjo, Soekidjo. Metodologi Penelitian Kesehatan Edisi Kedua. Jakarta: PT. Rineka Cipta; 2002.

7. Wong, L. D. Pedoman Klinis Perawatan Pediatrik (Wong and Whaley's Clinical Manual of Paediatrik Nursing). Alih bahasa: Monica Ester, edisi 4. EGC. Jakarta; 2004.

8. Krausen. Fisioterapi Oral, Jakarta: EGC; 1985.

9. Hidayat, AA. Prosedur Penelitian Kebidanan: Teori dan Praktek. Jakarta: Rineka Cipta; 2007.

10. Prawirohardjo, Sarwono. Pelayanan Kesehatan Maternal dan Neonatal. Jakarta: YBP-SP; 2005.

11. Doenges, Marilynn, E. Rencana Asuhan Keperawatan Psikiatri. Edisi 3. Jakarta: EGC; 2006.

12. Bobak, M. I., Lowdermilk, D.L., Jensen, M. D., Perry, S. E. Buku Ajar; 2007.

Keperawatan Maternitas Edisi 4.Jakarta : EGC

13. Utami, Roesli. "Inisiasi menyusu dini plus ASI eksklusif." Jakarta: Pustaka Bunda (2008): 2-31. 